\title{
HUBUNGAN KOMITMEN KERJA DAN KECERDASAN EMOSIONAL DENGAN PRESTASI KERJA PEGAWAI AKADEMI KEPERAWATAN KABUPATEN KOLAKA
}

\author{
Evodius Nasus
}

Program studi keperawatan Program Diploma Tiga, Fakultas Sains dan TeknologiUniversitas Sembilanbelas November, Kab. Kolaka, Sulawesi Tenggara

e-mail :evonasususn@gmail.com

\begin{abstract}
ABSTRAK
Penelitian ini bertujuan untuk menguji dan menganalisis secara empiris pengaruhmotivasi kerja, komitmen kerja dan kecerdasan emosional terhadap prestasi kerja pegawai pada Akademi Keperawatan Pemerintah Kabupaten Kolaka. Penelitian ini bersifat explanatory yang bermaksud menjelaskan kedudukan variabelvariabel yang diteliti serta hubungan dan pengaruh antara satu variabel dengan variabel yang lain. Hasil penelitian menunjukkan bahwa: (1) Motivasi kerja, komitmen kerja dan kecerdasan emosional berpengaruh positif dan signifikan terhadap prestasi kerja pegawai pada Akademi Keperawatan Pemerintah Kabupaten Kolaka. (2) Motivasi kerja berpengaruh positif dan signifikan terhadap prestasi kerja pegawai pada Akademi Keperawatan Pemerintah Kabupaten Kolaka.(3) Komitmen kerja berpengaruh positif dan signifikan terhadap prestasi kerja pegawai pada Akademi Keperawatan Pemerintah Kabupaten Kolaka.(4) Kecerdasan emosional berpengaruh positif dan signifikan terhadap prestasi kerja pegawai pada Akademi Keperawatan Pemerintah Kabupaten Kolaka.
\end{abstract}

Kata Kunci: Motivasi Kerja, Komitmen Kerja, Kecerdasan Emosional dan Kinerja Pegawai

\section{ABSTRACT}

This study aimed to examine and analyze empirically the effect of working motivation, working commitment, and emotional intelligence on the working achievement of staff at Kolaka Government's Academy of Nursing. The study was an explanatory research which aimed at explaining the position of variables under investigation as well as the relationship between them and the effect of one variable on the others. Results showed that: (1) working motivation, working commitment, and emotional intelligence had a positively significant effect on the working achievement of staff at Kolaka Government's Academy of Nursing; (2) working motivationhad a positively significant effect on the working achievement of staff at Kolaka Government's Academy of Nursing; (3) working commitment had a positively significant effect on the working achievement of staff at Kolaka Government's Academy of Nursing; and (4) emotional intelligence had a positively significant effect on the working achievement of staff at Kolaka Government's Academy of Nursing.

Keywords: working motivation, working commitment, emotional intelligence, performance of staff

PENDAHULUAN

Dalam suatu organisasi,

sumber daya manusia memegang peranan yang sangat penting karena faktor manusia (man) menentukan kelangsungan hidup daripada suatu organisasi sehingga tidak ada satupun organisasi yang tidak melibatkan manusia dalam merealisasi tujuannya[1]. Manusia merupakan salah satu dari beberapa faktor produksi yang sangat sulit dikendalikan, hal ini disebabkan oleh adanya ciri dan sifat khusus dari faktor produksi tersebut 
sehingga seringkali menimbulkan kesulitan-kesulitan apabila tidak dipahami dengan baik [2].

Faktor sumber daya manusia ini merupakan elemen yang harus diperhatikan oleh organisasi, terutama bila mengingat bahwa era pelayanan digital akan segera dimulai dimana komitmen dan kecerdasan emosional yang dihadapi akan sangat berbeda. Hal ini memaksa setiap organisasi harus dapat bekerja dengan lebih efisien, efektif dan produktif. Tingkatan komitmen dan kecerdasan emosional yang tinggi akan memacu tiap organisasi untuk dapat mempertahankan kelangsungan hidupnya dengan memberikan perhatian pada aspek sumber daya manusia. Jadi manusia dapat dipandang sebagai faktor penentu karena ditangan manusialah segala inovasi akan direalisir melalui peningkatan prestasi kerja pegawai dalam upaya mewujudkan tujuan organisasi [3].

Aparatur Sipil Negara (ASN) adalah profesi bagi Pegawai Negeri Sipil (PNS) dan Pegawai Pemerintah dengan Perjanjian Kerja (PPPK) yang bekerja pada instansi pemerintah. Pegawai ASN terdiri dari PNS dan PPPK yang diangkat oleh pejabat pembina kepegawaian dan diserahi tugas dalam suatu jabatan pemerintahan atau diserahi tugas negara lainnya dan digaji berdasarkan peraturan perundangundangan [4].

$$
\text { Dalam UU ASN }
$$

mengedepankan independensi, kinerja dan profesionalisme ASN. Jabatan dalam UU ASN terdiri dari jabatan fungsional, jabatan administratif serta jabatan pimpinan tinggi, istilah PNS diganti menjadi ASN, dan ada perubahan batas usia pensiun yang semula 56 tahun diperpanjang menjadi 58 tahun sementara pejabat pimpinan tinggi (eselon I dan II) 60 tahun. Perubahan-perubahan tersebut didasarkan pada sistem merit, yang lebih menekankan profesionalisme, kualitas, kompetensi, kinerja, obyektivitas, transparansi serta bebas dari intervensi politik dan praktik KKN untuk pengisian jabatan [4].

Penilaian kinerja di Akademi Keperawatan Pemerintah Kabupaten Kolaka menggunakan dua cara, yaitu penilaianperilaku kerja dan penilaian perencanaan kerja atau yang biasa disebutdengan Sasaran Kerja Pegawai (SKP). SKP dilaksanakan dari tahun 2014sehubungan dengan dikeluarkannya Peraturan Pemerintah Republiklndonesia Nomor 46 Tahun 2011 Tentang Penilaian Prestasi PegawaiNegeri Sipil. Peraturan tersebut meminta seluruh pegawai untuk membuatperencanaan kerja yang akan dilakukan selama kurun waktu satu tahunyang berguna untuk kenaikan pangkat. Perencanaan kinerja ini dilakukanoleh masing-masing pegawai dalam waktu satu tahun yang nantinya outputkinerjanya akan dijadikan sebagai penilaian kuantitas oleh Akademi Keperawatan Pemerintah Kabupaten Kolaka.

Salah satu cara yang dapat di tempuh untuk meningkatkan prestasi kerja pegawai adalah dengan peningkatan komitmen dan kecerdasan emosional.dan keberhasilan organisasi tempatnya bekerja [5]. Pegawai dengan komitmen yang tinggi merasakan adanya loyalitas dan rasa memiliki 
terhadap organisasi. Loyalitas menunjukkan makna bahwa pegawai bersedia untuk melanggengkan pengaruhnya dengan organisasi melalui penerimaan sasaran, nilai-nilai organisasi, kesediaan atau kemauan untuk berusaha menjadi bagian dari organisasi, serta keinginan untuk bertahan di dalam organisasi [6].

Komitmen seseorang terhadap organisasi (organizational commitment) seringkali menjadi isu yang sangat penting di dalam dunia kerja. Komitmen terhadap organisasi menyiratkan pengaruh pegawai dengan organisasi secara aktif. Pegawai yang menunjukkan komitmen yang tinggi memiliki keinginan untuk memberikan tenaga dan tanggung jawab yang lebih dalam menyokong kesejahteraan [7].

Refrensi [8] mendefinisikan komitmen kerja sebagai hubungan psikologis antara seseorang dengan pekerjaannya yang didasarkan pada reaksi afektif terhadap pekerjaan tersebut. Selanjutnya juga dikatakan bahwa seseorang yang memiliki komitmen kerja yang tinggi akan lebih kuat mengidentifikasikan dirinya dengan pekerjaan tersebut dan mengalami lebih banyak perasaan positif mengenai pekerjaannya.

Kecerdasan emosional adalah bagian dari kecerdasan sosial yang melibatkan kemampuan untuk memonitor emosi diri sendiri dan perasaan orang lain, untuk membedakan antara mereka, dan menggunakan informasi untuk memandu seseorang berpikir dan tindakan. Seseorang yang mengenal emosi diri sendiri dan mampu dengan baik membaca emosi orang lain dapat menjadi lebih efektif dalam pekerjaan [9], [10]. Menurut Refrensi [11], menyatakan bahwa dalam studi yang menyoroti tentang emosi terhadap motivasi menyarankan terhadap organisasi untuk mendorong emosi yang positif dalam pekerjaan berkemungkinan besar akan lebih memiliki tenaga kerja yang termotivasi yang secara langsung berimplikasi pada peningkatan prestasi kerja.

Di dalam sejumlah ulasan tentang kecerdasan emosional, dikemukakan kecerdasan emosional jauh lebih penting daripada kecerdasan dan kemampuan intelektual seseorang dalam mempengaruhi kesuksesan hidupnya [12]. Salah satu hal yang mendasari pandangan ini adalah gejolak perasaan sangat mempengaruhi proses berpikir. Misalnya, saat individu sedang marah, konsentrasinya mulai terganggu dan kemudian mempengaruhi proses pengambilan keputusan [13].

Pihak manajemen Akademi Keperawatan Pemerintah Kabupaten Kolaka juga mengalami kendala mengenai rendahnya komitmen kerja dan kecerdasan emosional yang dapat dilihat dari ketidaktahuan pegawai pada uraian tugas yang dimiliki, rendahnya perhatian akan tugas, hubungan kerja pegawai yang kurang harmonis dimana masih adanya pegawai yang terlibat pertengkaran yang disebabkan perbedaan argumen dalam bekerja, kurangnya perhatian serta dukungan pegawai kepada rekan kerja yang sedang mengalami permasalahan dalam bekerja, masih adanya pegawai yang kurang percaya diri dalam bekerja dan masih adanya pegawai yang memiliki luapan emosi berlebihan ketika 
mengalami permasalahan dalam bekerja. Komitmen kerja yang rendah disinyalir sebagai implikasi dari rendahnya komitmen kerja pegawai sehingga pegawai merasa tertekan secara psikologis terhadap pekerjaan yang dihadapi berdampak pada pegawai pegawai yang sering menggunakan emosi dalam bekerja, sifat egoisme pegawai yang menonjol sehingga manyebabkan penurunan prestasi kerja pegawai [14].

\section{METODOLOGI}

$\begin{array}{rlll}\text { Penelitian ini bersifat } & Y & =\text { Variabel Prestasi kerja Pegawai } \\ \text { explanatory dimana yang umumnya } & \beta_{1} & =\text { Koefisien regresi } X_{1} \\ \text { bertujuan untuk menjelaskan kedudukan } & X_{1} & =\text { Variabel Motivasi Kerja } \\ \text { variabel-variabel yang diteliti serta } & \beta_{2} & =\text { Koefisien regresi } X_{2} \\ \text { hubungan dan pengaruh antara satu } & X_{2} & =\text { Variabel Komitmen Kerja } \\ \text { variabel dengan variabel yang lain [15]. } & \beta_{3} & =\text { Koefisien regresi } X_{3} \\ \text { Populasi dalam penelitian ini } & X_{3} & =\text { Variabel Kecerdasan Emosional } \\ \text { adalah seluruh pegawai pada Akademi } & \text { e } & =\text { Faktor kesalahan } \\ \text { Keperawatan Pemerintah Kabupaten } & \beta_{0} & =\text { Konstanta (asumsi }=0)\end{array}$

Kolaka. Total pegawai pada Akademi Keperawatan Pemerintah Kabupaten Kolaka adalah 37 pegawai tidak termasuk pimpinan pada Akademi Keperawatan Pemerintah Kabupaten Kolaka.Metode penarikan responden dalam penelitian ini menggunakan metode sensus yaitu metode penarikan sampel yang jumlah sampelnya sama dengan jumlah populasi yaitu berjumlah 37 orang pegawai pada Akademi Keperawatan Pemerintah Kabupaten Kolaka.

Metode analisis yang digunakan adalah metode analisis statistika inferensial dengan model regresi linear berganda, dengan rumus regresi berganda:

$Y=\beta_{0}+\beta_{1} X_{1}+\beta_{2} X_{2}+\beta_{2} X_{2}+e$

Dimana :

\section{HASIL DAN PEMBAHASAN}

\section{Karakteristik Responden}

Distibusi responden berdasarkan usia, jenis kelamin, tingkat pendidikan dan masa kerja adalah sebagai berikut

$$
\text { Tabel } 1 \text { Karakteristik Responden }
$$

\begin{tabular}{ccc}
\hline Karakteristik Responden & $\begin{array}{c}\text { Jumlah responden } \\
(\mathrm{n}=37)\end{array}$ & Persentase (\%)
\end{tabular}

\begin{tabular}{lcc}
\hline Usia (Tahun) & 14 & 37,84 \\
$24-30$ & 7 & 18,92 \\
$31-37$ & 12 & 32,43 \\
$38-44$ & 4 & 10,81 \\
$\geq 45$ & & \\
Jenis Kelamin & 20 & 54,05 \\
Laki-laki & 17 & 45,95 \\
Perempuan & & \\
Tingkat Pendidikan & 6 & 16,22 \\
D3 & 21 & 56,76 \\
S1 & &
\end{tabular}




\section{Masa Kerja}

6-10

Sumber : Data Primer Di Olah Tahun 2017

Berdasarkan karakteristik usia responden didapatkan data pegawai yang berusia 24-30 tahun sebanyak 14 orang atau $37,84 \%, 38-44$ tahun sebanyak 12 orang atau $32,43 \%, 31-37$ tahun sebanyak 7 orang atau $18,92 \%$ dan 45 tahun keatas sebanyak 4 orang atau $10,81 \%$ dari 37 pegawai pada Akademi Keperawatan Pemerintah Kabupaten Kolaka. Berdasarkan identifikasi data diatas, dapat kita ketahui bahwa mayoritas pegawai pada Akademi Keperawatan Pemerintah Kabupaten Kolaka berada pada usia 2430 tahun. Usia tersebut merupakan usia produktif bagi pegawai yang memberikan keuntungan bagi Akper Pemda Kolaka untuk memaksimalkan potensi kerja pegawai agar dalam setiap pelaksanaan pekerjaan dapat terselesaikan dengan kualitas dan tepat waktu yang diperoleh dari dukungan dari rekan kerja dan pimpinan, komitmen pegawai untuk terus berkontribusi dan kepuasan pegawai atas capaian hasil kerja.

Data tentang karakteristik jenis kelamin menunjukkan bahwa sebanyak 20 orang atau $54,05 \%$ pegawai pada Akademi Keperawatan Pemerintah Kabupaten Kolaka adalah pria sedangkan wanita sebanyak 17 orang atau $45,95 \%$ dari pegawai pada Akademi Keperawatan Pemerintah Kabupaten Kolaka. Berdasarkan identifikasi data yang dilakukan, pegawai pada Akademi Keperawatan Pemerintah Kabupaten Kolaka didominasi oleh pria, Dengan demikian dapat dikatakan bahwa pegawai pada Akademi Keperawatan Pemerintah Kabupaten Kolaka dapat diprediksikan hubungan-hubungan individual dalam organisasi lebih dominan didasarkan pada hubungan rasionalitas sebagaimana salah satu ciri khas kaum pria [16]. Pegawai dengan jenis kelamin pria pada dasarnya cenderung memiliki semangat kerja, keuletan dan kegigihan dalam melaksanakan pekerjaan. Pegawai dengan jenis kelamin pria juga dianggap memiliki tingkat mobilisasi yang sangat tinggi dalam bekerja [17].

Berdasarkan karakteristik tingkat pendidikan responden menunjukkan bahwa sebanyak 21 orang atau $56,76 \%$ pegawai pada Akademi Keperawatan Pemerintah Kabupaten Kolaka berpendidikan $S_{1}$. Sebanyak 10 orang atau $27,03 \%$ berpendidikan $S_{2}$. Sebanyak 6 orang atau 16,22\% berpendidikan Sarjana Muda. Dengan demikian dapat dikatakan bahwa ratarata pegawai pada Akademi Keperawatan Pemerintah Kabupaten Kolaka memiliki pendidikan tingkat sarjana. Tingkat pendidikan pada dasarnya ikut mempengaruhi bagaimana pengetahuan pegawai dalam menyelesaikan tugas-tugasnya. Tingkat pendidikan pegawai pada Akademi Keperawatan Pemerintah 
Kabupaten Kolaka tergolong pada tingkatan sarjana karena didominasi oleh pegawai dengan tingkat pendidikan $\mathrm{S}_{1}$. Pegawai yang berpendidikan lebih tinggi akan dengan sangat mudah untuk saling melakukan komunikasi kerja, konsuling dan saling memberikan pengetahuan baru dalam pelaksanaan kerja [18].

Berdasarkan karakteristik masa kerja responden didapatkan bahwa sebanyak 16 orang atau 43,24\% pegawai pada Akademi Keperawatan Pemerintah Kabupaten Kolaka telah bekerja 10 tahun ke atas. Kemudian pegawai bermasa kerja antara 1-5 tahun sebanyak 14 orang atau $37,84 \%$ dan selebihnya sebanyak 7 orang atau $18,92 \%$ adalah mereka yang bekerja antara 6-10 tahun. Dengan demikian dapat dikatakan bahwa sebagian besar pegawai pada Akademi Keperawatan Pemerintah Kabupaten Kolaka memiliki masa kerja yang cukup sehingga diharapkan memiliki kinerja yang tinggi. Pegawai dengan masa kerja yang cukup lama tentunya telah memiliki pengalaman dalam menghadapi setiap permasalahan kerja. Untuk itu, pegawai dengan pengalaman kerja yang cukup banyak dengan masa kerja yang rendah memiliki potensi dalam meningkatkan kinerja pegawai [19].

\section{Variabel Komitmen kerja}

Berdasarkan hasil penelitian yang diperoleh melalui kuisioner, maka kondisi obyektif untuk variabel komitmen kerja yang dimaksudkan dalam penelitian ini diukur dengan 4 (empat) indikator, yakni: (1) kesesuaian orientasi hidup dengan tugas/pekerjaan, (2) perhatian terhadap tugas/pekerjaan, (3) besarnya waktu yang diluangkan untuk tugas/pekerjaan dan (4) kesediaan untuk selalu terlibat dalam tugas/pekerjaan.

Tabel 2 Distribusi Jawaban Responden Terhadap Komitmen Kerja

\begin{tabular}{|c|c|c|c|c|c|c|c|c|c|c|c|c|}
\hline \multirow{3}{*}{$\begin{array}{c}\text { Item } \\
\text { (butir) }\end{array}$} & \multicolumn{10}{|c|}{ Frekuensi Jawaban Responden (f) dan Persentase (\%) } & \multirow{3}{*}{$\begin{array}{l}\text { Total } \\
\text { Skor }\end{array}$} & \multirow{3}{*}{$\begin{array}{l}\text { Rata } \\
\text {-rata }\end{array}$} \\
\hline & \multicolumn{2}{|c|}{ SS } & \multicolumn{2}{|c|}{$\mathbf{S}$} & \multicolumn{2}{|r|}{$\mathbf{N}$} & \multicolumn{2}{|r|}{ TS } & \multicolumn{2}{|c|}{ STS } & & \\
\hline & $F$ & $\%$ & $F$ & $\%$ & $F$ & $\%$ & $\mathbf{F}$ & $\%$ & $F$ & $\%$ & & \\
\hline $\mathrm{X}_{2.1}$ & $\begin{array}{l}1 \\
2\end{array}$ & 32,43 & 11 & $\begin{array}{c}29,7 \\
3\end{array}$ & 5 & $\begin{array}{c}13,5 \\
1\end{array}$ & 6 & 16,22 & 3 & 8,11 & 134 & 3,62 \\
\hline$X_{2.2}$ & $\begin{array}{l}1 \\
3\end{array}$ & 35,14 & 5 & $\begin{array}{c}13,5 \\
1\end{array}$ & 8 & $\begin{array}{c}21,6 \\
2\end{array}$ & 7 & 18,92 & 4 & 10,81 & 127 & 3,43 \\
\hline $\mathrm{X}_{2.3}$ & 9 & 24,32 & 8 & $\begin{array}{c}21,6 \\
2\end{array}$ & 9 & $\begin{array}{c}24,3 \\
2\end{array}$ & 7 & 18,92 & 4 & 10,81 & 122 & 3,30 \\
\hline$X_{2.4}$ & $\begin{array}{l}1 \\
1 \\
\end{array}$ & 29,73 & 7 & $\begin{array}{c}18,9 \\
2\end{array}$ & 6 & $\begin{array}{c}16,2 \\
2\end{array}$ & 9 & 24,32 & 4 & 10,81 & 123 & 3,32 \\
\hline \multicolumn{11}{|c|}{ Rata-rata Skor Indikator Variabel Komitmen Kerja $\left(\mathrm{X}_{2}\right)$} & 506 & 3,42 \\
\hline
\end{tabular}

Dapat diketahui bahwa variabel komitmen kerja yang diterapkan oleh Akademi Keperawatan Pemerintah Kabupaten Kolaka berada pada kategori baik yang ditunjukan dengan nilai ratarata skor penilaian untuk variabel komitmen kerja sebesar 3,42. Hal ini menunjukkan bahwa pegawai pada Akademi Keperawatan Pemerintah Kabupaten Kolaka telah menerapkan sistem komitmen kerja dengan sangat baik yang dapat meningkatkan kinerja pegawai. 
Hasil penelitian deskriptif ini menunjukkan bahwa variabel komitmen kerja untuk indikator kesesuaian orientasi hidup dengan tugas/pekerjaan merupakan indikator yang sangat dominan pada variabel komitmen kerja dengan nilai rata-rata 3,62 dengan katagori sangat baik. Sedangkan, indikator besarnya waktu yang diluangkan untuk tugas/pekerjaan menjadi indikator dengan nilai rata-rata terendah untuk variabel komitmen kerja dengan besaran nilai rata-rata sebesar 3,30. Akan tetapi nilai tersebut masih berada dalam kategori baik. Hal ini disebabkan presepsi responden dalam menanggapi tergolong rendah disebabkan masih adanya pegawai yang menyelesaikan pekerjaan tidak tepat waktu yang mempengauhi pelayanan pada Akademi Keperawatan Pemerintah Kabupaten Kolaka .

Namun masih ada sebagian pegawai yang memilih jawaban tidak setuju dan sangat tidak setuju. Faktor penyebab responden memilih jawaban tidak setuju dan sangat tidak setuju adalah masih adanya pegawai pada Akademi Keperawatan Pemerintah Kabupaten Kolaka yang mempersepsikan rendah terhadap indikator komitmen kerja diantaranya adalah masih adanya pegawai yang tidak memberikan perhatian dan waktu terhadap pekerjaan diluar jam kerja, masih adanya pegawai tidak mau terlibat terhadap akitivitas kerja yang diperintahkan pimpinan, masih adanya pegawai yang menganggap kestidak sesuaian apa yang dimiliki baik dari segi pengetahuan, keahlian dengan posisi atau jabatan yang diemban.

Berdasarkan informasi di atas, maka pihak Akademi Keperawatan Pemerintah Kabupaten Kolaka dipandang perlu untuk meningkatkan komitmen kerja pegawai yang dapat memberikan keuntungan terhadap peningkatan prestasi kerja. Komitmen kerja mampu menumbuhkan semangat kerja, keterlibatan kerja yang berdampak langsung terhadap loyalitas pegawai pada Akademi Keperawatan Pemerintah Kabupaten Kolaka.

\section{Variabel Kecerdasan Emosional}

Berdasarkan hasil penelitian yang diperoleh melalui kusioner, maka kondisi objektif untuk variabel kecerdasan emosional yang dimaksudkan dalam penelitian ini diukur dengan 5 (lima) indikator, yakni: (1) self awareness, (2) self management, (3) motivasi, (4) empatidan (5) relationship management. 
Tabel 3 Distribusi Jawaban Terhadap Variabel Kecerdasan Emosional

\begin{tabular}{|c|c|c|c|c|c|c|c|c|c|c|c|c|}
\hline \multirow{3}{*}{$\begin{array}{l}\text { Item } \\
\text { (Butir) }\end{array}$} & \multicolumn{10}{|c|}{$\begin{array}{l}\text { Frekuensi Jawaban Responden (f) dan Persentase } \\
\qquad(\%)\end{array}$} & \multirow{3}{*}{$\begin{array}{c}\text { Tota } \\
\text { I } \\
\text { Skor }\end{array}$} & \multirow{3}{*}{$\begin{array}{c}\text { Rata } \\
\text { - } \\
\text { Rata }\end{array}$} \\
\hline & \multicolumn{2}{|c|}{ SS (5) } & \multicolumn{2}{|c|}{$S(4)$} & \multicolumn{2}{|c|}{$N(3)$} & \multicolumn{2}{|c|}{ TS (2) } & \multicolumn{2}{|c|}{ STS (1) } & & \\
\hline & $F$ & $\%$ & $\mathbf{F}$ & $\%$ & $\mathbf{F}$ & $\%$ & $\mathbf{F}$ & $\%$ & $\mathbf{F}$ & $\%$ & & \\
\hline$X_{3.1}$ & $\begin{array}{l}1 \\
1\end{array}$ & $\begin{array}{c}29,7 \\
3\end{array}$ & $\begin{array}{l}1 \\
2\end{array}$ & $\begin{array}{c}32,4 \\
3\end{array}$ & 8 & $\begin{array}{c}21,6 \\
2\end{array}$ & 4 & $\begin{array}{c}10,8 \\
1\end{array}$ & 2 & 5,41 & 137 & 3,70 \\
\hline$X_{3.2}$ & $\begin{array}{l}1 \\
1\end{array}$ & $\begin{array}{c}29,7 \\
3\end{array}$ & 7 & $\begin{array}{c}18,9 \\
2\end{array}$ & 6 & $\begin{array}{c}16,2 \\
2\end{array}$ & 8 & $\begin{array}{c}21,6 \\
2\end{array}$ & 5 & $\begin{array}{c}13,5 \\
1\end{array}$ & 122 & 3,30 \\
\hline$X_{3.3}$ & $\begin{array}{l}1 \\
8\end{array}$ & $\begin{array}{c}48,6 \\
5\end{array}$ & $\begin{array}{l}1 \\
1\end{array}$ & $\begin{array}{c}29,7 \\
3\end{array}$ & 4 & $\begin{array}{c}10,8 \\
1\end{array}$ & 2 & 5,41 & 2 & 5,41 & 152 & 4,11 \\
\hline$X_{3.4}$ & 9 & $\begin{array}{c}24,3 \\
2\end{array}$ & $\begin{array}{l}1 \\
0\end{array}$ & $\begin{array}{c}27,0 \\
3\end{array}$ & 8 & $\begin{array}{c}21,6 \\
2\end{array}$ & 7 & $\begin{array}{c}18,9 \\
2\end{array}$ & 3 & 8,11 & 126 & 3,41 \\
\hline$X_{3.5}$ & $\begin{array}{l}1 \\
1\end{array}$ & $\begin{array}{c}29,7 \\
3\end{array}$ & $\begin{array}{l}1 \\
2 \\
\end{array}$ & $\begin{array}{c}32,4 \\
3\end{array}$ & $\begin{array}{l}1 \\
0\end{array}$ & $\begin{array}{c}27,0 \\
3\end{array}$ & 3 & 8,11 & 1 & 2,70 & 140 & 3,78 \\
\hline
\end{tabular}

Dapat diketahui bahwa variabel

kecerdasan emosional yang diterapkan oleh pihak Akademi Keperawatan Pemerintah Kabupaten Kolaka berada pada kategori baik yang ditunjukan dengan nilai rata-rata skor penilaian untuk variabel kecerdasan emosional sebesar 3,66. Hal ini menunjukkan bahwa pegawai pada Akademi Keperawatan Pemerintah Kabupaten Kolaka telah memiliki kecerdasan emosional dengan sangat baik yang dapat meningkatkan kinerja pegawai.

Hasil penelitian deskriptif ini menunjukkan bahwa variabel kecerdasan emosional untuk indikator motivasi merupakan indikator yang sangat dominan pada variabel kecerdasan emosional dengan nilai rata-rata 4,11 dengan katagori sangat baik. Sedangkan indikator self management menjadi indikator dengan nilai rata-rata terendah untuk variabel kecerdasan emosional dengan besaran nilai rata-rata sebesar 3,30.

Namun masih ada sebagian pegawai yang memilih jawaban tidak setuju dan sangat tidak setuju. Faktor penyebab responden memilih jawaban tidak setuju dan sangat tidak setuju adalah masih adanya pegawai pada

Akademi Keperawatan Pemerintah

Kabupaten Kolaka yang mempersepsikan rendah terhadap indikator kecerdasan emosional diantaranya adalah masih adanya pegawai yang tidak mampu menahan emosi sehingga pegawai dirasa terlambat untuk mengambil keputusan, pegawai tidak mau bekerjasama dengan rekan kerja.

Berdasarkan informasi di atas, maka pihak Akademi Keperawatan Pemerintah Kabupaten Kolaka dipandang perlu untuk membangun dan meningkatkan hubungan kerja yang profesional dengan menciptakan kepercayaan antar pegawai, pimpinan juga harus memberikan dorongan/motivasi kepada pegawai melalui pendekatan psikologis yang dapat meningkatkan prestasi kerja pegawai.

\section{Variabel Prestasi Kerja}

Berdasarkan hasil penelitian yang diperoleh melalui kusioner, maka kondisi objektif untuk variabel prestasi kerja yang dimaksudkan dalam penelitian ini diukur dengan 4 (empat) item indikator, yakni: (1) kuantitas kerja, (2) kualitas kerja, (3) kreativitas dan (4) integritas. 
Tabel 4 Distribusi Jawaban Responden Terhadap Variabel Prestasi Kerja

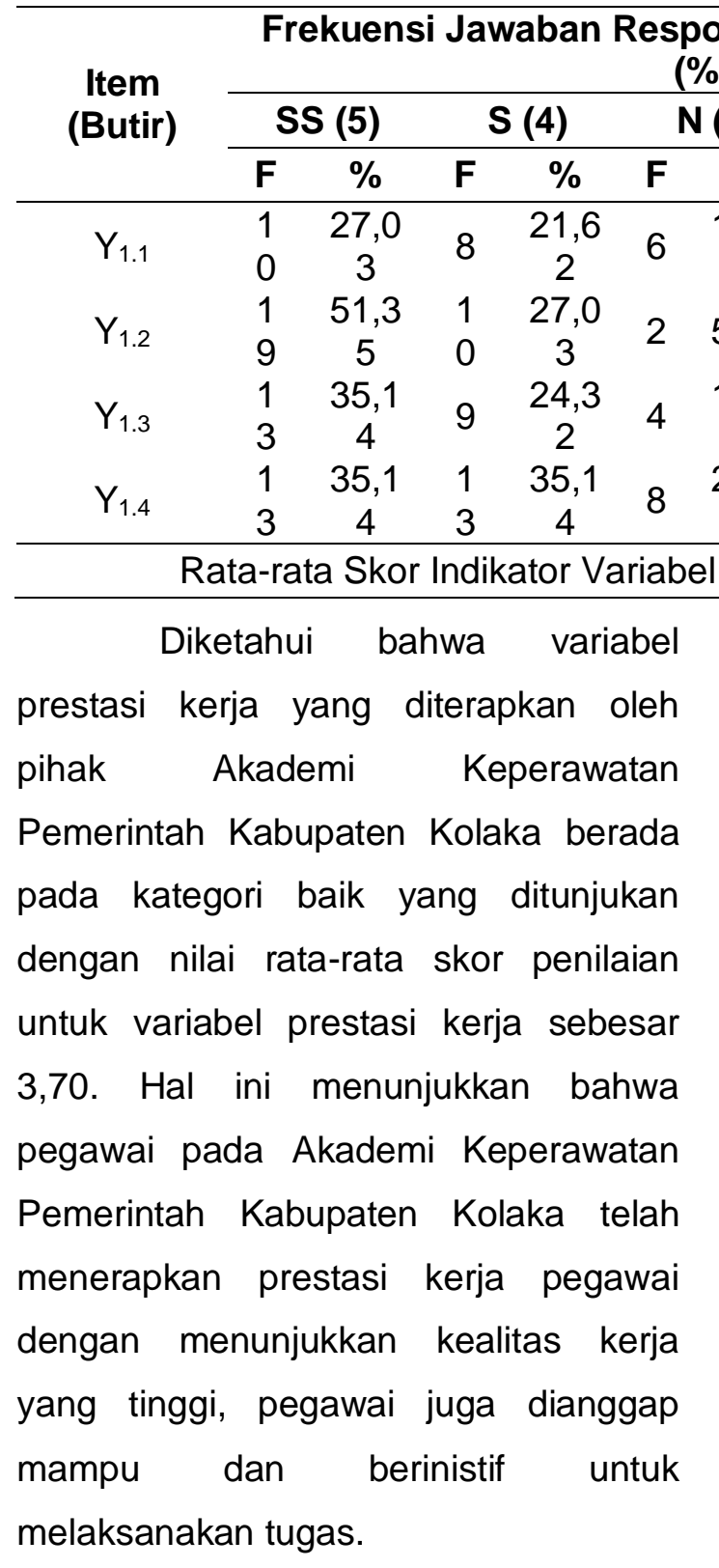

Hasil penelitian deskriptif ini menunjukkan bahwa variabel prestasi kerja untuk indikator kualitas kerja merupakan indikator yang sangat dominan pada variabel prestasi kerja dengan nilai rata-rata 4,00 dengan katagori sangat baik. Sedangkan indikator kuantitas kerja menjadi indikator dengan nilai rata-rata terendah untuk variabel prestasi kerja dengan besaran nilai rata-rata sebesar 3,30. Akan tetapi nilai tersebut masih berada dalam kategori baik. Hal ini disebabkan presepsi responden dalam menanggapi tergolong rendah disebabkan masih adanya pegawai yang menyelesaikan pekerjaan tidak tepat waktu yang ponden (f) dan Persentase

\%) Tota Rata

$\begin{array}{llc}\text { N (3) } & \text { TS (2) } & \text { STS (1) } \\ \text { S I }\end{array}$

$\begin{array}{ccccccc}16,2 & 9 & 24,3 & 4 & 10,81 & 122 & 3,30\end{array}$

$\begin{array}{lllllll}5,41 & 1 & 2,70 & 5 & 13,51 & 148 & 4,00\end{array}$

$\begin{array}{ccccccc}10,8 & 7 & 18,9 & 4 & 10,81 & 131 & 3,54\end{array}$

$\begin{array}{ccccccc}21,6 & 2 & 5,41 & 1 & 2,70 & 146 & 3,95\end{array}$

Prestasi Kerja $(Y) \quad 547 \quad 3,70$
mempengaruhi pelayanan pada

Akademi Keperawatan Pemerintah Kabupaten Kolaka .

Namun masih ada sebagian pegawai yang memilih jawaban tidak setuju dan sangat tidak setuju. Faktor penyebab responden memilih jawaban tidak setuju dan sangat tidak setuju adalah masih adanya pegawai pada Akademi Keperawatan Pemerintah Kabupaten Kolaka yang mempersepsikan rendah terhadap indikator prestasi kerja diantaranya adalah masih adanya pegawai yang tidak mempunyai disiplin kerja sehingga pegawai kurang maksimal dalam melaksanakan kerja, pegawai tidak memiliki kreativitas dalam bekerja untuk memudahkan penyelesaian pekerjaan.

Berdasarkan informasi di atas, maka pihak Akademi Keperawatan Pemerintah Kabupaten Kolaka dipandang perlu untuk meningkatkan kemampuan dan keahlian kerja pegawai melalui motivasi kerja dan pelatihan serta pembimbingan yang dilakukan pimpinan, hal ini dapat meningkatkan kualitas hasil kerja dan kecepatan waktu penyelesaian pekerjaan. Hal lain yang juga dapat dilakukan ialah mendorong pegawai untuk melaksanakan kerjasama serta 
kemandirian kerja untuk meningkatkan kreativitas dan integritas pegawai terhadap pekerjaan.

\section{Hasil Analisis}

Tabel 5 Hasil Analisis Regresi Linear Berganda

\begin{tabular}{lcccc}
\hline \multicolumn{1}{c}{ Variabel Bebas $(\mathbf{X})$} & $\begin{array}{c}\text { Koefisien } \\
\text { Regresi } \\
(\boldsymbol{\beta})\end{array}$ & $\mathbf{t}_{\text {Hitung }}$ & $\begin{array}{c}\mathbf{t}_{\text {signifika }} \\
\mathbf{n}\end{array}$ & $\begin{array}{c}\text { Keteranga } \\
\mathbf{n}\end{array}$ \\
\hline Komitmen Kerja $\left(\mathrm{X}_{1}\right)$ & 0,316 & 2,878 & 0,007 & $\begin{array}{c}\text { Signifikan } \\
\text { Kecerdasan Emosional }\left(\mathrm{X}_{2}\right)\end{array}$ \\
\hline Konstanta $\left(\beta_{0}\right)=1,621$ dengan t signifikan 0,200 & 0,464 & 4,253 & 0,000 & Signifikan \\
R Square & & & $\mathrm{N}=37$ \\
$\mathrm{R}$ & $=0,814$ & & $\alpha=0,05$ \\
Standar error $=0,902$ & & &
\end{tabular}

Signifikansi pengaruh variabel

$\mathrm{X}_{1}$ (komitmen kerja) terhadap $\mathrm{Y}$ (prestasi kerja pegawai) diperoleh nilai $t$ hitung $\left(t_{0,05}=2,878\right)$ dengan nilai $t_{\text {sig }}=$ $0,007<0,05)$. Hasil ini mengindikasikan bahwa nilai koefisien $\beta_{2}$ sebesar 0,316 secara statistika berbeda nyata dengan nol $(0,316 \neq 0)$. Dengan demikian dapat dinyatakan bahwa secara parsial variabel $X_{1}$ berpengaruh nyata terhadap $Y$. Artinya variabel $X_{1}$ (komitmen kerja) dapat menjadi salah satu variabel penduga atau variabel prediktor yang kuat bagi variabel $\mathrm{Y}$ (prestasi kerja pegawai). Karena itu variabel komitmen kerja dapat dimasukkan dalam model pendugaan prestasi kerja pegawai pada Akademi Keperawatan Pemerintah Kabupaten Kolaka.

Signifikansi pengaruh variabel $\mathrm{X}_{2}$ (kecerdasan emosional) terhadap $\mathrm{Y}$ (prestasi kerja pegawai) diperoleh nilai $t$ hitung $\left(\mathrm{t}_{0,05}=4,253\right)$ dengan nilai $t_{\text {sig }}=$ $0,000<0,05)$. Hasil ini mengindikasikan bahwa nilai koefisien $\beta_{3}$ sebesar 0,464 secara statistika berbeda nyata dengan nol $(0,464 \neq 0)$. Dengan demikian dapat dinyatakan bahwa secara parsial variabel $X_{2}$ berpengaruh nyata terhadap $\mathrm{Y}$. Artinya variabel $\mathrm{X}_{2}$ (kecerdasan emosional) dapat menjadi salah satu
Untuk membuktikan hipotesis penelitian yang diajukan dalam penelitian ini, digunakan metode regresi linear berganda

variabel penduga atau variabel prediktor yang kuat bagi variabel $\mathrm{Y}$ (prestasi kerja pegawai). Karena itu variabel kecerdasan dapat dimasukkan dalam model pendugaan prestasi kerja pegawai pada Akademi Keperawatan Pemerintah Kabupaten Kolaka.

Berdasarkan hasil pengujian model regresi secara parsial di ketahui bahwa nilai thitung pada taraf $\alpha=0,05$ sebesar 2,878 dan nilai $t_{\text {sig }}$ sebesar 0,007 ( $\left.t_{\text {sig }}=0,007\right)$ berarti nilai $t_{\text {sig }}<$ 0,05.Maka komitmen kerja berpengaruh terhadap prestasi kerja pegawai pada Akademi Keperawatan Pemerintah Kabupaten Kolaka. Hal ini dapat di interpretasikan bahwa semakin tinggi komitmen kerja maka akan semakin tinggi pula prestasi kerja pegawai. Karakteristik responden mempunyai keterkaitan erat dengan komitmen kerja, pegawai dengan jenis kelamin laki-laki memiliki kecenderungan lebih menunjukkan komitmen terhadap pekerjaannya. Hal ini dapat dilihat dari lebih tingginya mobilitas serta semangat kerja pegawai. Pegawai dengan masa kerja yang sangat lama juga dianggap memiliki komitmen kerja yang tinggi, hal ini dikarenakan pegawai dengan masa kerja yang lama memiliki pengalaman 
yang dapat memudahkan penyelesaian pekerjaannya.

Hasil yang didapatkan ini sejalan dengan studiyang dilakukan oleh Refrensi [20] yang menyatakan komitmen kerja memiliki pengaruh signifikan terhadap prestasi kerja. Alasan yang mendasari sesuai kondisi empirik ialah pegawai Akademi Keperawatan Pemerintah Kabupaten Kolaka memiliki komitmen kerja yang sangat tinggi. Hal ini dapat dilihat perilaku pegawai yang terus berperan aktif dalam setiap proses belajar mengajar dan pelayanan kepada mahasiswa. Pegawai memberikan perhatian yang sangat baik dan bersedia meluangkan waktu untuk bersama-sama menganalisa suatu permasalahan ataupun perkembangan terbaru di bidang keperawatan medis, pegawai juga mampu untuk memberikan pelayanan administrasi kepada mahasiswa dan rekan kerja dengan kualitas yang tinggi. Komitmen kerja pegawai pada Akademi Keperawatan Pemerintah Kabupaten Kolaka membentuk loyalitas pegawai terhadap Akademi Keperawatan Pemerintah Kabupaten Kolaka

Berdasarkan hasil pengujian model regresi secara parsial di ketahui bahwa nilai thitung pada taraf $\alpha=0,05$ sebesar 4,253 dan nilai $t_{\text {sig }}$ sebesar $0,000\left(t_{\text {sig }}=0,003\right)$ berarti nilai $t_{\text {sig }}<$ 0,05. Hal tersebut dapat diartikan bahwa kecerdasan emosional berpengaruh terhadap prestasi kerja pegawai pada Akademi Keperawatan Pemerintah Kabupaten Kolaka. Hal ini dapat di interpretasikan bahwa semakin tinggi kecerdasan emosional maka akan semakin tinggi pula prestasi kerja pegawai.

Refrensi [12]menyatakan bahwa kemampuan terbesar yang mempengaruhi kesuksesan seseorang dalam bekerja adalah empati, disiplin diri dan inisiatif yang dikenal dengan nama kecerdasan emosional. Referensi [21] mendefiniskan kecerdasan emosi merupakan kemampuan emosi yang meliputi kemampuan untuk mengendalikan diri, memiliki daya tahan ketika menghadapi suatu masalah, mampu mengendalikan impuls, memotivasi diri, mampu mengatur suasana hati, kemampuan berempati dan membina hubungan dengan orang lain ${ }^{4}$. Teori lain yang juga mendukung hasil penelitian ini, Refrensi [21] menjelaskan kecerdasan emosional adalah kemampuan seseorang untuk: (1) sadar diri, mengenali emosi diri sendiri, (2) mendeteksi emosi orang lain, (3) mengelola emosi dan informasi, dalam hubungannya dengan orang lain. Jika seseorang mampu mengetahui emosi diri sendiri dan membaca emosi orang lain, maka dengan mudah mengetahui bahwa mereka sedang marah dan bagaimana mengekspresinya. Sehingga akan lebih efektif dalam bekerja.

Sejalan dengan studi yang dilakukan oleh Refrensi [23] yang menyatakan bahwa kecerdasan emosional memiliki pengaruh terhadap prestasi kerja pegawai. Alasan yang mendasari sesuai dengan kondisi empirik ialah pegawai Akademi Keperawatan Pemerintah Kabupaten Kolaka memiliki kecerdasan emosional yang sangat tinggi. Hal ini dapat dilihat kemampuan pegawai dalam 


\begin{abstract}
mengendalikan emosi untuk melaksanakan pekerjaan, emosi tersebut mendorong pegawai untuk melaksanakan pekerjaan dengan cermat dan penuh tanggung jawab.
\end{abstract}

\section{KESIMPULAN}

1. Komitmen kerja berpengaruh positif dan signifikan terhadap prestasi kerja pegawai pada Akademi Keperawatan Pemerintah Kabupaten Kolaka. Artinya bahwa komitmen kerja yang baik memiliki kontribusi dalam peningkatan prestasi kerja pegawai pada Akademi Keperawatan Pemerintah Kabupaten Kolaka.

2. Kecerdasan emosional berpengaruh positif dan signifikan terhadap prestasi kerja pegawai pada Akademi Keperawatan Pemerintah Kabupaten Kolaka. Artinya semakin baik kecerdasan emosional maka akan meningkatkan prestasi kerja pegawai pada Akademi Keperawatan Pemerintah Kabupaten Kolaka.

\section{DAFTAR PUSTAKA}

1. Siagian, Sondang P. 2014. Manajemen Sumber Daya Manusia. Jakarta

2. Stephen Pilbeam, Marjorie Corbridge. 2002. People Resourcing Human Resourcer Management in Practice. 2nd Edition. England Prentice Hall.

3. Dessler, Gary.2003. Human Resource Management Tenth Edition. New Jersey: Prentice Hall.

4. Badan Kepegawaian Negara. Undang-Undang No. 5 Tahun 2014. www.bkn.go.id

5. Kristiwardhana, Aryo. 2011. Analisis Pengaruh Motivasi Kerja Dan Komitmen Organisasional Terhadap
Kinerja Karyawan (Studi Pada PT. BPR Estetika Artha Guna Semarang).

6. Djati, Pantja dan Khusaini. 2003. Kajian Terhadap Kepuasan Kompensasi, Komitmen Organisasi , dan Prestasi Kerja, Jurnal Manajemen dan Kewirausahaan, Vol.5, No.1, Maret 2003:25-41.

7. Setiati A. Dian , 2002, Strategi Organisasi : Perbedaan Produktivitas dan Komitmen Organisasional,Teori Motivasi Abraham Maslow, Amara Books, Cet.l, h.157.

8. Lee, S., Carswell, J. P., \& Allen, N. J. 2000. Foundations of Behavioral Research. Fourth Edition. Hartcourt Brace College Publishers, Florida.

9. Plutchik, R. 2002. Emotions and Life perspective from psychology, biology, and evolution. Washington, DC: American Psychological Association.

10. Purba, Ahmad.1999. Emotional Intelligence, Seri Ayah Bunda, 26 Juli-8 Agustus, Dian Raya, Jakarta.

11. Robbins, Stephen P. dan Judge, Timothy A., 2009. Organizational Behavior. 13th Edition. Pearson Education, Inc., Upper Saddle River, New Jersey

12. Goleman, D, 2000, Kecerdasan Emosi : Mengapa Emotional Intelligence LebihTinggi Daripada IQ, Alih Bahasa : T. Hermay, PT. Gramedia Pustaka Utama, Jakarta.

13. Mayer, J.D., Caruso, D., \& Salovey, P. 1999. Emotional Intelligence meets Traditional standards for an intelligence. Intelligence,27,267-298.

14. Patton, P, 1998, Kecerdasan Emosional di Tempat Kerja, Alih 
Bahasa : Zaini Dahlan, Pustaka Delaprata, Jakarta

15. Sugiyono. 2001. Metode Penelitian Bisnis, Cetakan Ketiga, Alfabeta, Bandung.

16. Steers, R.M and Porter, R. W 1983. Motivation and Work Behavior. New York: Mc Graw Hill.

17. Herawati, Nur And Sasana, Hadi. 2013. Analisis Pengaruh

Pendidikan, Upah Pengalaman Kerja, Jenis Kelamin Dan Umur Terhadap Produktivitas Tenaga Kerja Industri Shutllecock Kota Tegal.Universitas Diponegoro

18. Wirawan, Bagia, S. 2013. Pengaruh Tingkat Pendidikan dan Pengalaman Kerja terhadap Kinerja Karyawan. E-Journal Bisma Universitas Pendidikan Ganesha Jurusan Manajemen, 4(1), 1-8.

19. Kurniawati, irma dwi. 2014. hubungan masa kerja dengan job engagement karyawan. 02(02), 311-324.

(DOI: https://doi.org/10.22219/jipt.v2i 2.2005)

20. Kusuma, Lingga Sakti. 2014. Pengaruh Motivasi Kerja Dan Kepuasan Kerja Terhadap Organizational Citizenship Behavior Pegawai RRI Yogyakarta. Fakultas Ekonomi Universitas Negeri Yogyakarta.

21. Goleman, D., 2009. Emotsional'nyi intellekt (Emotional intelligence), Moscow: AST,

22. Luthans F., Youssef M. C. \& Avolio J. B. 2007. Psychological capital : Developing the human competitive edge. New York. Oxford University Press Inc.
23. Subagio, M. 2017. Pengaruh Kecerdasan Emosional, Motivasi Kerja, Dan Sikap Kerja Terhadap Kinerja Karyawan Pada Pt Ithaca Resources. Jurnal Manajemen, 19(1),101.https://doi.org/10.24912/j m.v19i1.108 